\title{
Change in risk of breast cancer after receiving hormone replacement therapy by considering effect-modifiers: a systematic review and dose-response meta-analysis of prospective studies
}

\author{
Kang Wang ${ }^{1}$, Feng Li ${ }^{2}$, Li Chen ${ }^{1}$, Yan-Mei Lai ${ }^{1}$, Xiang Zhang ${ }^{1, *}$ and Hong-Yuan Li $^{1, *}$ \\ ${ }^{1}$ Department of the Endocrine and Breast Surgery, The First Affiliated Hospital of Chongqing Medical University, Chongqing \\ Medical University, Chongqing, 400016, China \\ ${ }^{2}$ Department of Neurosurgery, The Second Affiliated Hospital of Chongqing Medical University, Chongqing Medical University, \\ Chongqing, 400016, China \\ *These authors contributed equally to this work and should be considered as co-corresponding author \\ Correspondence to: Hong-Yuan Li, email: hongy_li@hotmail.com \\ Xiang Zhang, email: 85910545@qq.com
}

Keywords: breast cancer, hormone replacement therapy, estrogen-alone therapy, estrogen plus progestin therapy, body mass index

Received: June 02, $2017 \quad$ Accepted: July 30, $2017 \quad$ Published: August 11, 2017

Copyright: Wang et al. This is an open-access article distributed under the terms of the Creative Commons Attribution License 3.0 (CC BY 3.0), which permits unrestricted use, distribution, and reproduction in any medium, provided the original author and source are credited.

\section{ABSTRACT}

We synthesize the current literatures and use the power of meta-analysis to examine trends on association between hormone replacement therapy (HRT) and the risk of breast cancer (BC). We performed a comprehensive literature search using PubMed, EMBASE, and Web of Science from their inception until Jan 2017. Prospective studies that provided adjusted risk estimates of HRT and BC risk were eligible. Categorical and dose-response meta-analyses followed the PRISMA were conducted using random effects model and restricted cubic spline model, respectively. Fortyseven publications from thirty-five unique studies were included, involving 3,898,376 of participants and 87,845 of BC cases. Compared with non-users, RR for current estrogen-only therapy (ET) users was 1.14 (95\% confidence interval (CI) = 1.05-1.22), and for per year increases was $1.02(95 \% \mathrm{CI}=1.02-1.02)$. Moreover, RR for current estrogen plus progestin therapy (EPT) users was $1.76,(95 \% \mathrm{CI}=$ 1.56-1.96), and for per year increases was 1.08 (95\% CI =1.08-1.08). Dose-response analyses revealed 8-10 years' onset peaks, and indicated residual increased BC risk remained after stopping use of ET regimen rather than for EPT. Effect-modifiers like BMI, duration of use, race/ethnicity, routes of administration were recognized. In Conclusions, current use of EP or EPT and ever use of tibolone are associated with an elevated risk of BC. Compared with slim HRT users and non-users, lower BC risks were found among overweight/obese HRT users and former EPT users, respectively. Both ET and EPT users are associated with higher risk of lobular BC than ductal BC, and more ER-positive than negative BC cases were detected among EPT users.

\section{INTRODUCTION}

After increasing breast cancer (BC) risk among hormone replacement therapy (HRT) users was detected by Women's Health Initiative (WHI) Randomized Clinical Trial (RCT) in 2002 [1], HRT were challenged by International Agency for Research on Cancer (IARC) $[2,3]$. This cancer accounts for leading incidence as well as second cause of death in women cancers [4]. Overwhelming evidence from current decade showed a striking disparity between estrogen-alone therapy (ET) and estrogen plus progestin therapy (EPT) regimens in incidence of BC [5-12], recommending that scholars should not combine any HRT regimens when examining $\mathrm{BC}$ risk [13].

Although the relationship between EPT use and elevated $\mathrm{BC}$ risk has been well established, newly 
developing perspectives and issues were difficult to interpret according to prior evidences [12, 14, 15]. For instance, the tendency of $\mathrm{BC}$ risk changes over time when extending to a long-term use ( $>10$ years) of EPT, and whether increased EPT-associated BC risk drops after stopping it [7, 9]. Additionally, some effect-modifiers and interactions were mentioned for precise risk assessment, such as age [16], race/ethnicity [13], body mass index (BMI) $[5,7,9,17-21]$, progestin type [5, 22-24], route of administration $[5,22,25]$, mode of EPT combination $[5,18,21-24,26]$, characteristics of $\mathrm{BC}[11,18,19]$, and gap time between menopause and starting use EPT [19, 27]. Similarly, the discrepancy in BC risk was observed among ET users according to these inconsistent factors. Most observational studies [5, 8, 9, 20, 26, 27] are characterized as inadequate for weighing this risk because of these potential effect-modifiers.

Given the comparable elevated risk with unopposed estrogen use in development endometrial cancer [28], ET is usually applied to subjects undergone hysterectomy. Interestingly, low-level endogenous estradiol [29] or estrogen antagonist (e.g. tamoxifen [30], oophorectomy [31] and menopause [15].) had been certified as BC risk reduction factors, indicating that estrogen exerts a promotional effect on developing $\mathrm{BC}$, while there has been no verdict regarding inconsistent results shown by epidemiological studies. The WHI RCT [32] showed no additional $\mathrm{BC}$ risk among 5,310 women receiving $0.625 \mathrm{mg} /$ day conjugated equine estrogens(CEE) compared with placebo group, instead, BC incidence is lower but without significant difference detected. Nevertheless, considering increased stroke risk and no overall favorable risk to benefit ratio, the trial had to be ended after 7.2 years' intervention [32]. When followed-up duration extended to more than 10 years after initial intervention, this potential benefit not only sustained but also became notable throughout the early post-intervention phase [7]. In contrast, some large, prospective, population-based observational studies consistently indicated an association between ET use and increased risk of BC, such as Million Women Study [27], Nurses' Health Study [33], California Teachers Study [18] and a Danish cohort [23], raising uncertainty on the magnitude of ET-related BC risk. There were inevitable potential biases as misclassification of actual use [34], menopausal age [6] and unsatisfied adherence to treatment may apparently lead to inconsistent results. Meanwhile, BMI profile should be comparable when discussing this ambiguous correlation, which is a critical factor for 'estrogen paradox' $[35,36]$.

We carried out a systematic review with doseresponse meta-analyses of different HRT regimens and subsequent BC in order to identify the shape of utility and withdrawal associated time-response and quantify the precise outcomes and the effects of potential interactions on HRT-related BC.

\section{MATERIALS AND METHODS}

\section{Literature search}

This systematic review with meta-analysis was conducted and reported in accordance with PRISMA guideline [37]. A comprehensive literature search was performed using PubMed, EMBASE, and Web of Science from their inception until Jan 2017 (date last searched), which included truncated free text and explored mesh terms. The detailed search strategies were showed in Supplementary Table 1. To avoid missing studies, we manually checked the reference lists of previous reviews. No attempt was made to identify unpublished reports. If necessary, the original authors were contacted to obtain extra information via e-mails.

\section{Study selection}

RCTs, prospective cohort studies and nested casecontrol studies that assessed HRT (i.e. EPT, ET, PT) as exposure variables and $\mathrm{BC}$ as an outcome and supplied risk estimates with 95\% confidence interval (CI) were eligible for categorical analyses. To conduct dose-response analyses, quantitative exposures (duration or time from quitting of HRT use and BMI) had to be available additionally, and $\mathrm{BC}$ cases and person-years in each quantitative category should be reported. We employed the studies with longer followed-up and more detailed data under the condition that multiple publications reported the same database. Nevertheless, some overlapping publications with detailed information, not for main analysis, were exploited for subgroup analyses. Two investigators (L.C. and F.L.) independently screened titles and abstracts to identify the potentially suitable publications, then they evaluated these relevant articles based on full-texts reviewing. Any discrepancies were solved through consensus.

\section{Data extraction and quality assessment}

Data extraction was performed by one investigator (F.L.), and was then checked independently for the accuracy by another investigator (L.C.). The following information was extracted: first author, year of publication, study location, sample size, BC cases, mean age, exposure or interventional variables, mean follow-up duration, $\mathrm{BC}$ assessment and maximally adjusted risk estimate with corresponding 95\% confidence interval (CI) and adjustment factors.

We assessed the quality of identified studies using the Newcastle-Ottawa quality assessment scale (NOS) [38]. To evaluate its 3 aspects (selection, comparability, and outcome), nine stars could be awarded to each study at most (4 stars for selection; 3 stars for comparability; 
2 stars for outcome). The quality of studies ranks as low quality (below 3 stars), moderate quality (4-6 stars), high quality (7-9 stars). Any disagreements on the results of data extraction and quality assessment were resolved by further discussion.

\section{Statistical methods}

We performed categorical and dose-response metaanalysis, and random effects model was used to pool risk estimates [39]. Relative risk (RR) was adopted to evaluate the association between HRT use and the risk of BC. Hazard ratio (HR) [6-9, 40-42], odds ratio (OR) [43], incidence rate ratio (IRR) $[21,44]$ and standardized incidence ratio (SIR) [22] were considered as equivalent to RR simultaneously. Maximally adjusted RRs were employed to yield summary results, which were calculated using the average of natural logarithm RRs of eligible studies, and weighted by the inverse of the variance, whereas unadjusted RRs from the RCT [7] was also included.

Categorical meta-analysis was conducted by pooling basic classification results involving HRT regimens (i.e. ET, EPT and other HRT regimens) at different use statuses (i.e. current, former). The reference category was individuals never using HRT, and exposure group was current, former and ever HRT users responsible for above classifications, depending on studies. When categorical results were stratified by age [40], pathology [20, 45, 46], subjects undergo operations [33] and duration of use [9], we combined subgroup specific outcomes using fixed effects model to generate an uniquely categorical effect.

The random-effect dose-response on account of generalized least squares trend estimation proposed and developed by Orsini and Greenland [47, 48] was used to explore RR with $95 \%$ CI for per 1 unit increase from linear trend on association between duration of HRT use or quitting (year) or BMI $\left(\mathrm{kg} / \mathrm{m}^{2}\right)$ among HRT users and the risk of $\mathrm{BC}$, respectively, and a goodness-of-fit $c h i^{2}$ with $P_{\text {goodness-of-fit }}$ was calculated to test the suitability of the Restricted cubic spline models were applied to nonlinear dose-response analysis using spline transformations with three knots at the 10th, 50th and 90th percentile $[49,50]$, and a $P_{\text {non-linearity }}$ value for curve linearity or nonlinearity was calculated by testing the null hypothesis that the estimated value of the second spline is equal to zero [49]. The models were based on specific exposure level, distribution of cases, person-years and the RRs with 95\% CIs for at least three quantitative categories. We formulated means or medians of the quantitative categories as each exposure level, if not reported in studies, the estimated midpoint must be available. Furthermore, if the highest category was open ended, midpoint of whose category was assigned at same adjacent with the lower boundary. When the lowest category was open-ended, we set the lower boundary to zero. In particular, $15 \mathrm{~kg} / \mathrm{m}^{2}, 18.5 \mathrm{~kg} / \mathrm{m}^{2}$ and $40 \mathrm{~kg} / \mathrm{m}^{2}$ were employed as lowest bound and highest bound supposing that studies reported results by WHO categories of underweight $\left(<18.5 \mathrm{~kg} / \mathrm{m}^{2}\right)$, normal $\left(18.5-25 \mathrm{~kg} / \mathrm{m}^{2}\right)$ and obesity $\left(>30 \mathrm{~kg} / \mathrm{m}^{2}\right)$, respectively. Of BMI categories with non-zero level as reference $[6,7,18,20,21,45]$, we adopted method of Hamling and colleagues [51] to convert risk estimates when reference group was not the lowest category. Meanwhile, when we explored dose-response associations of time since last HRT use and BC risk, current HRT use was considered as reference group after similar transformations. For some studies, whose original researchers did not report person years by exposure level $[8,41,52]$, we approximately derived such data from follow-up duration and the number of participants at each quantitative category.

Subgroup analysis and meta-regression [53] with a $P_{\text {interaction }}$ were performed stratified by duration of current use, time since last HRT use, baseline characteristics of participants (i.e. age at study entry, race/ethnicity, BMI), types of hormone component, route of administration (i.e. oral, virginal, transdermal), mode of EPT combination (i.e. sequential, continuous), characteristics of BC (i.e. stage, histology, ER/PR status). Particularly, age and race/ ethnicity were study-level factors which were identified by population characteristics, instead the rest of variables deriving from categorical outcomes in primary studies were employed to conduct precise subgroup analyses. In addition, we respectively presented dose-response analyses results on duration of HRT use and BC risk with $25 \mathrm{~kg} / \mathrm{m}^{2}$ and 5 years as the boundary values adopt by most studies to assess potential interaction effects from BMI and gap time.

To identify potential heterogeneity, we calculated Q statistic $\left(P_{\text {Heterogeneity }}<0.10\right.$ suggesting statistically significance) and the $\mathrm{I}^{2}$ statistic [54], whose values of $0,25,50$, and $75 \%$ are regarded as no, low, moderate and high heterogeneity. Sensitivity analyses were conducted by ignoring a single study in turn. Small study or publication bias was assessed by Begg rank correlation test [55] and Egger linear regression test [56]. All analyses were conducted using STATA version 13.0 (Stata Corp, College Station, TX). $P<0.05$ was considered statistically significant. All statistical tests were two-sided.

\section{RESULTS}

\section{Literature search and study characteristics}

Figure 1 shows process and results from the literature search. 2350 articles were identified from the PubMed database, 2071 articles from the EMBASE database, and 1325 articles from the Web of Science database. A total of 4,617 studies remained after exclusion of duplicates, and we obtained 124 potential relevant studies by screening titles and abstracts. After full text reviewing, we excluded 79 studies for detailed reasons 


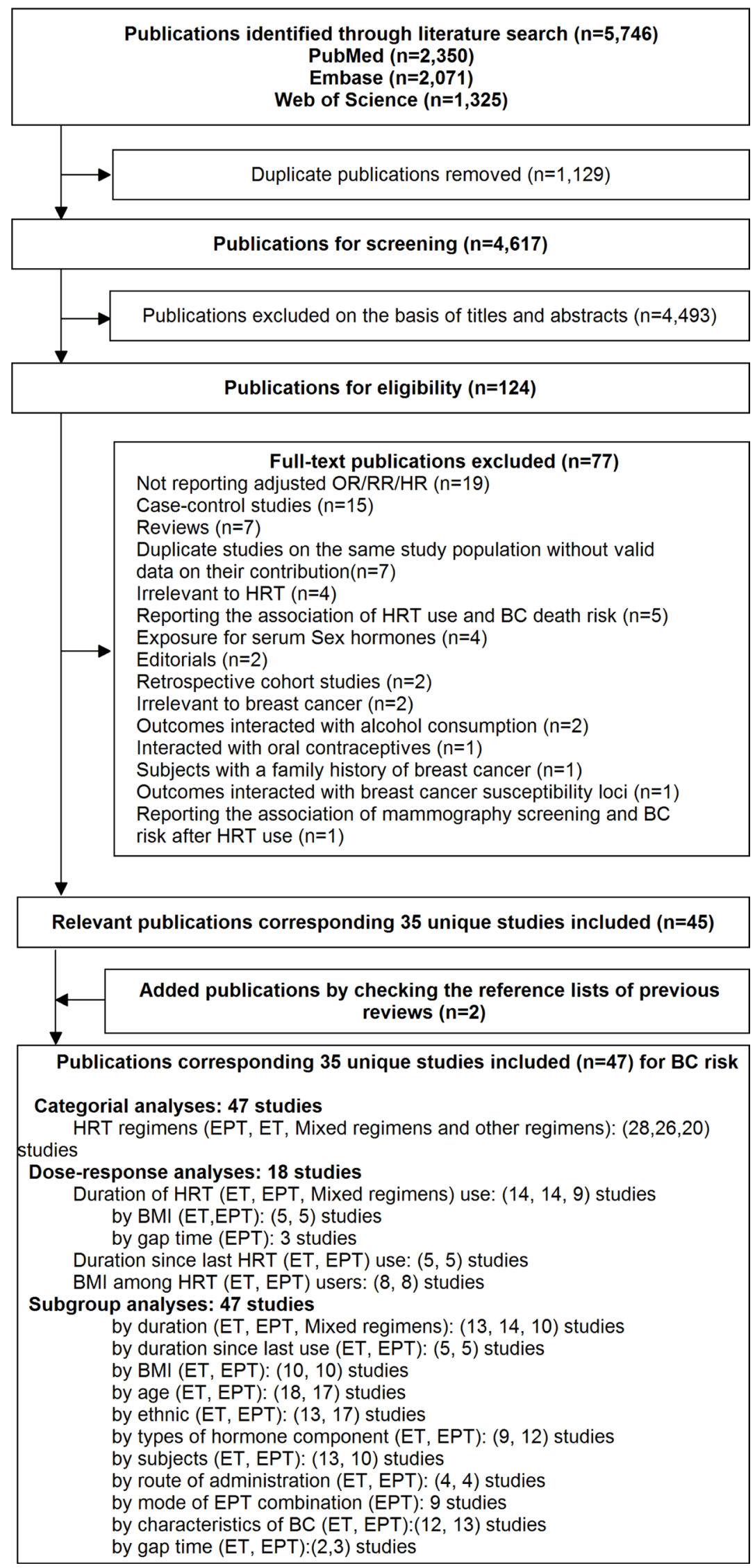

Figure 1: The flowchart of selecting eligible studies. 
showing in Supplementary Table 2. Additional $2[16,17]$ studies were eligible for inclusion in process of reviewing reference lists of prior reviews. At last, forty-seven publications from thirty-five unique studies were included, of which the characteristics shows in Supplementary Table 3. Some studies were reported using multiple publications, while we selectively included them for more comprehensive outcomes. Seven eligible publications $[1,7,13,32,57-59]$ reported results from WHI RCT and its subsequent observational study. Four eligible publications [9, 60-62] reported results from E3N cohort, and three $[11,27,34]$ reported on Million Women Study. Nurses' Health Study cohort was effectively reported by two publications $[19,33]$.

Thirteen studies were from Northern Europe [5, 22-24, 41, 42, 44, 46, 52, 63-66], 12 studies from USA $[8,17-21,26,43,67-70], 3$ studies from UK $[6,8,27], 3$ studies from France [9, 25, 71], 1study from Japan [40], 1study from Canada [72], 1study from Netherlands [73] and a [16] international study respectively. The average follow-up among prospective studies changed from 2.6 years [34] to 16.5 [19]. The sample size including the number of exposure and non-exposure (or placebo and intervention) population ranged from 1,334 [43] to $1,129,025$ [27], including 3,898,376 of participants and $87,845 \mathrm{BC}$ cases in total. Ascertainment methods of HRT exposure varied from studies, and most studies employed questionnaires to interview or mail participants $[6,8,9$, $16,17,20,21,23-26,41-44,46,52,63-73]$, in addition, medical records were used by others $[22,23,40]$. Twentysix studies $[6,7,9,16-19,21,23,26,27,40-43,46,52$, 63-69, 71, 73] awarded $\geq 7$ stars and remaining studies awarded 6 stars $[5,8,20,24,44,70]$ or 5 stars $[22,25,72]$, indicating the quality of included studies was generally good (Supplementary Table 4).

\section{$E T$ and $B C$ risk}

Figure 4 summarized results of categorical and dose-response analyses based on association between ET and the $\mathrm{BC}$ risk. Twenty-three studies were eligible for categorical analyses on relationship of current ET use and $\mathrm{BC}$ risk, including 8,054 $\mathrm{BC}$ cases among current users. The summary RR of $\mathrm{BC}$ risk in current users versus non-users of ET was $1.14(95 \% \mathrm{CI}=1.05-1.22)$ with substantial heterogeneity $\left(I^{2}=78.2 \%, P_{\text {heterogeneity }}<0.001\right.$, $n=23$ ). Five studies involving $1,017 \mathrm{BC}$ incidences among former ET users were included, whereas no elevated risk $(\mathrm{RR}=0.98,95 \% \mathrm{CI}=0.91-1.05)$ without heterogeneity $\left(I^{2}=1.8 \%, P_{\text {heterogeneity }}=0.4, n=5\right)$ was explored among former user.

The random-effect dose-response on account of generalized least squares trend estimation showed the RR per year increase on duration of EP use was 1.02 (95\% $\mathrm{CI}=1.02-1.02$, goodness-of-fit $\mathrm{chi}^{2}{ }_{42}=114.79$, $\left.P_{\text {goodness-offit }}<0.001, n=15\right)$. In addition, we also explored a non-linear association between duration of $\mathrm{ET}$ use and $\mathrm{BC}$ risk $\left(P_{\text {non-linearity }}=0.1\right)$ (Figure 2A) using restricted cubic spline model. The curve rose steeply and approximately reached the maximal RR at duration of 10 years, and declined slowly thereafter. Compared with current ET users, the dose-response association of time since last ET use and BC risk was found (RR for per year increase since last use $=0.99,95 \% \mathrm{CI}=0.98-0.99$, goodness-offit $c h i^{2}{ }_{18}=54.17, P_{\text {goodness-offit }}<0.001, n=6$ ), and a linearrelationship $\left(P_{\text {non-linearitv }}=0.45\right)$ (Figure $\left.2 \mathrm{~B}\right)$ indicated BC risk remained after going of ET regimen (RR for nonusers compared with current users $=0.82,95 \% \mathrm{CI}=0.71-$ $\left.0.93, I^{2}=63.5 \%, P_{\text {heterogeneity }}=0.02, n=6\right)($ Figure $4 \mathrm{~B})$. Additionally, among ET users, we found evidence of doseresponse association between individual $\mathrm{BMI}$ and $\mathrm{BC}$ risk (per 5 units in BMI profile for $\mathrm{RR}=0.93,95 \% \mathrm{CI}=0.91$ 0.95 , goodness-of-fit $\mathrm{chi}^{2}{ }_{17}=79.42, P_{\text {goodness-off-fit }}<0.001$, $n=8)$. An "U" shaped $\left(P_{\text {non-linearity }}=0.001\right)$ (Figure $\left.2 \mathrm{C}\right)$ relationship of BMI with BC risk was documented among ever ET users, and the minimum risk approximately rested on the level of $30 \mathrm{~kg} / \mathrm{m}^{2}$. Additionally, subgroup analyses, sensitivity analyses and publication biases were depicted in Table.1 and Supplementary Outcomes.

\section{EPT and $B C$ risk}

Table. 2 summarized results of categorical and doseresponse analyses based on association between EPT use and BC risk. Twenty-two studies were included in categorical analyses on relationship between EPT use and $\mathrm{BC}$ risk, including 17,584 cases among current EPT users. Compared with non-users, the summary RRs were 1.76 $(95 \% \mathrm{CI}=1.56-1.96, \mathrm{n}=22)$ for current EPT use and 1.06 $(95 \% \mathrm{CI}=0.93-1.20, \mathrm{n}=5)$ for former users. Substantial heterogeneity was observed between studies of current EPT users $\left(I^{2}=92 \%, P_{\text {heterogeneity }}<0.001\right)$, but not among former users $\left(I^{2}=48.3 \%, P_{\text {heterogeneity }}=0.1\right)$.

There was significant evidence of dose-response association between duration of EPT use and the risk of BC, and summary RR for per year increase was 1.08 (95\% $\mathrm{CI}=1.08-1.08$, goodness-of-fit $\mathrm{chi}^{2}{ }_{35}=296.40, P_{g}$ $<0.001, n=14)$. At the same time, we found a non-linear association $\left(P_{\text {non-linearity }}<0.001\right)$ (Figure 3A) between use time and $\mathrm{BC}$ risk, suggesting that an increasing trend displayed in first 5-year use and became gentle after that. Compared with current users, does-response relationship was detected according to time from EPT cessation and $\mathrm{BC}$ risk, indicating a dose-response association between per year increase in time since last EPT use and the risk of $\mathrm{BC}(\mathrm{RR}$ for per year increase since last use $=0.95,95 \%$ $\mathrm{CI}=0.94-0.96$, goodness-of-fit $\mathrm{chi}^{2}{ }_{16}=131.10, P$ $<0.0001$, RR for non-users $=0.48,95 \% \mathrm{CI}=0.28=0.69$, $\left.I^{2}=98.1 \%, P<0.001, \mathrm{n}=6\right)$, and a non-linear curve was revealed $\left(P_{\text {non-linearity }}<0.0001\right)$ (Figure 3B). This spline indicated no EPT-associated BC risk remained after 4 years' cessation, and potential benefit was observed. 
Linear dose-response relationship between BMI and the risk of BC among EPT users was found (RR for per 5 units increase in $\mathrm{BMI}=0.93,95 \% \mathrm{CI}=0.91-0.95$, goodness-offit $\left.\boldsymbol{c h i}^{2}{ }_{17}=237.69, P_{\text {goodness-of-fit }}<0.001, n=8\right)\left(P_{\text {non-linearity }}=\right.$ 0.37 ) (Figure $3 C$ ). Subgroup analyses, sensitivity analyses and publication biases were depicted in Figure 5 and Supplementary Outcomes.

\section{Other HRT regimens and $\mathrm{BC}$ risk}

Supplementary Table 5 summarized results of categorical and dose-response analyses based on association between Other HRT regimens and BC risk. Either mixed HRT regimens or tibolone was associated with increased $\mathrm{BC}$ risk (RR for mixed HRT regimens = $1.50,95 \% \mathrm{CI}=1.33-1.67, \mathrm{I}^{2}=91.3 \%, P_{\text {heterogeneity }}<0.001$, $\mathrm{n}=20$; RR for per year increase in duration of mixed HRT regimens use $=1.04,95 \% \mathrm{CI}=1.03-1.05$, goodness-of-fit chi $2_{35}=111.47, P_{\text {goodness-of-fit }}<0.001, \mathrm{n}=10$ (Supplementary Figure 4); RR for tibolone $=1.47,95 \% \mathrm{CI}=1.20-1.75, I^{2}$ $\left.=91.3 \%, P_{\text {heterogeneity }}=0.01, \mathrm{n}=5\right)$, whereas no association between PT use and the risk of $\mathrm{BC}$ was found $(\mathrm{RR}=$
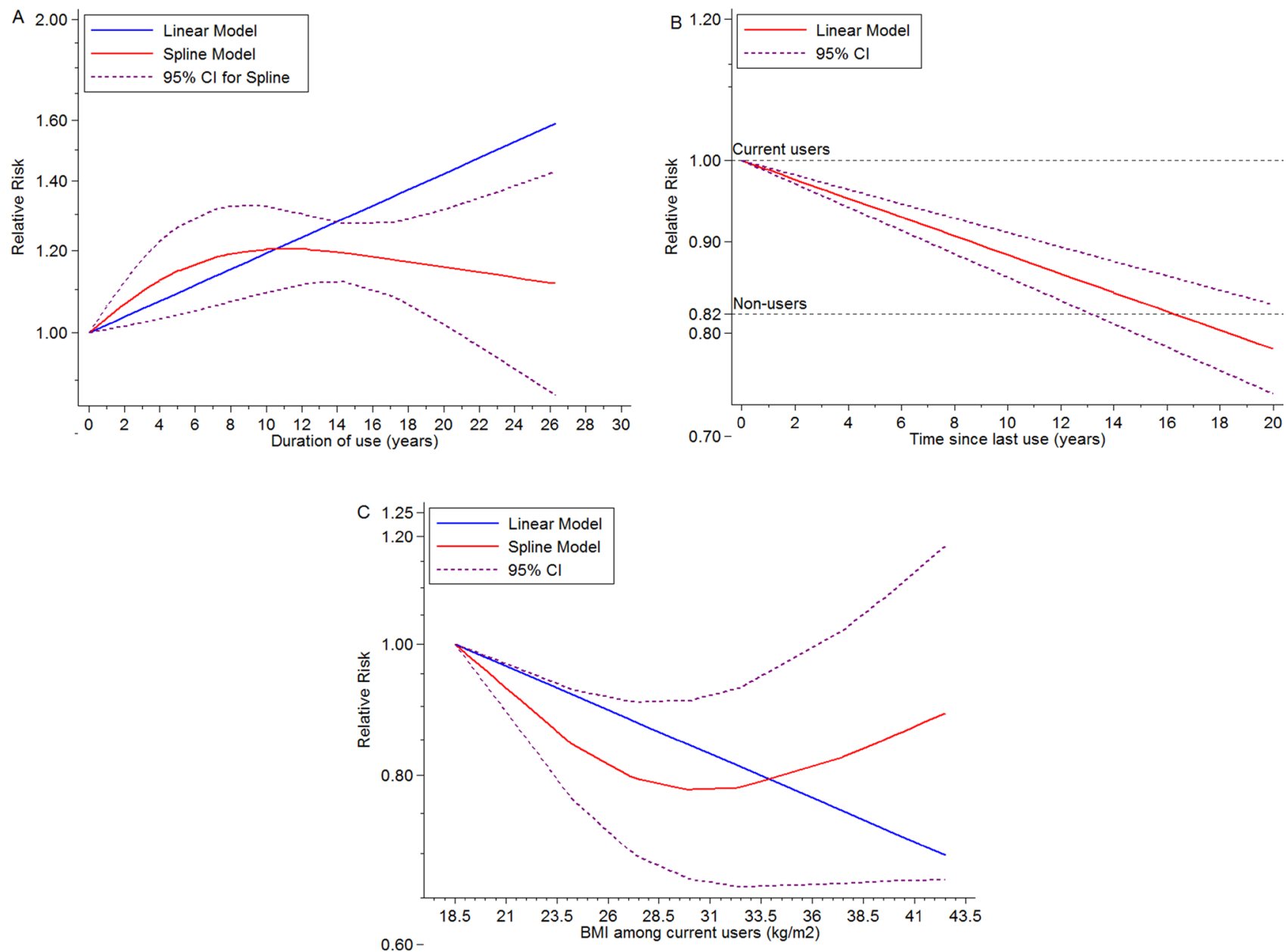

Figure 2: Dose-response meta-analyses on (A) duration of ET use (year) and the risk of BC compared with non-users, (B) time (year) since last ET use and the risk of BC compared with current ET users, $(\mathbf{C})$ BMI $(\mathrm{kg} / \mathrm{m} 2)$ and the risk of BC among current ET users. 
associated with higher risk of lobular $\mathrm{BC}$ than ductal $\mathrm{BC}$, while more ER-positive BC cases than ER-negative BC were detected among EPT users.

Current thinking suggested that the level of EPTassociated $\mathrm{BC}$ risk seems to be greater than that of ET [74]. Either endogenous or exogenous of estrogen levels were generally considered as a causal role in the etiology of $\mathrm{BC}[75,76]$, and a proposed hypothesis deeming that the carcinogenic effect of estrogens was augmented by progesterone [77, 78] explained disparity of two regimens, which is consistent with our results in regard to no association between PT and the risk of BC. Several robust mechanisms were addressed for two components based on this hypothesis via vivo or vitro studies [79, 80]. The carcinogenic effect of estrogen owned to increasing the mitotic rate of malignant or normal breast epithelium cells or combining its metabolites to exert effect [79, 80], contrarily, the progesterone indirectly realized synergies [81]. Additionally, we observed more risk of $\mathrm{BC}$ in subjects starting to use EPT or ET regimens less than 5 years after menopause, but no statistically significant BC risk was obtained when gap time $>5$ years. HRT users with a long time from menopause to first HRT exposure
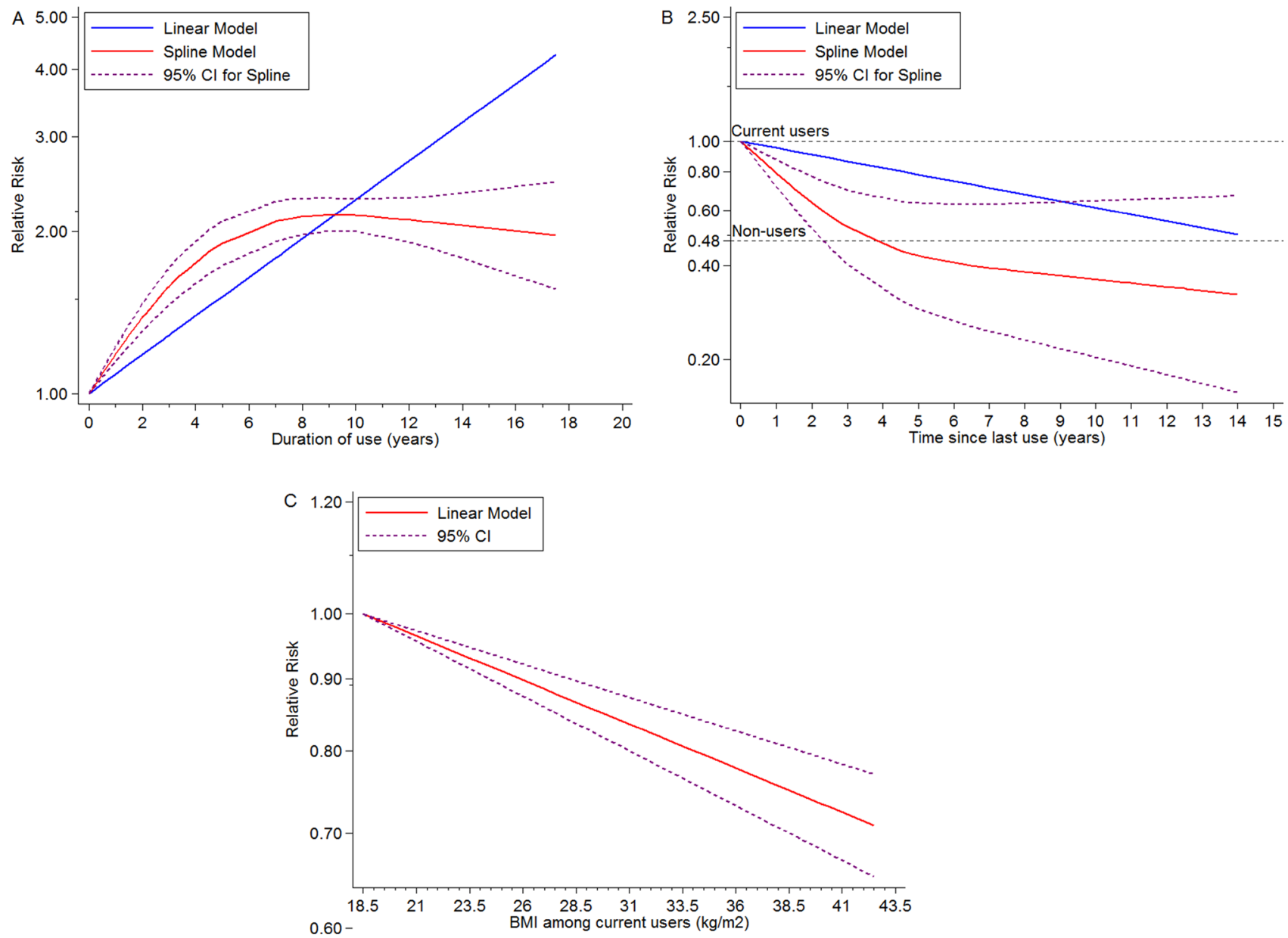

Figure 3: Dose-response meta-analyses on (A) duration of EPT use (year) and the risk of BC compared with non-users, (B) time (year) since last ET use and the risk of BC compared with current ET users, (C) BMI ( $\mathrm{kg} / \mathrm{m} 2)$ and the risk of BC among current ET users. 


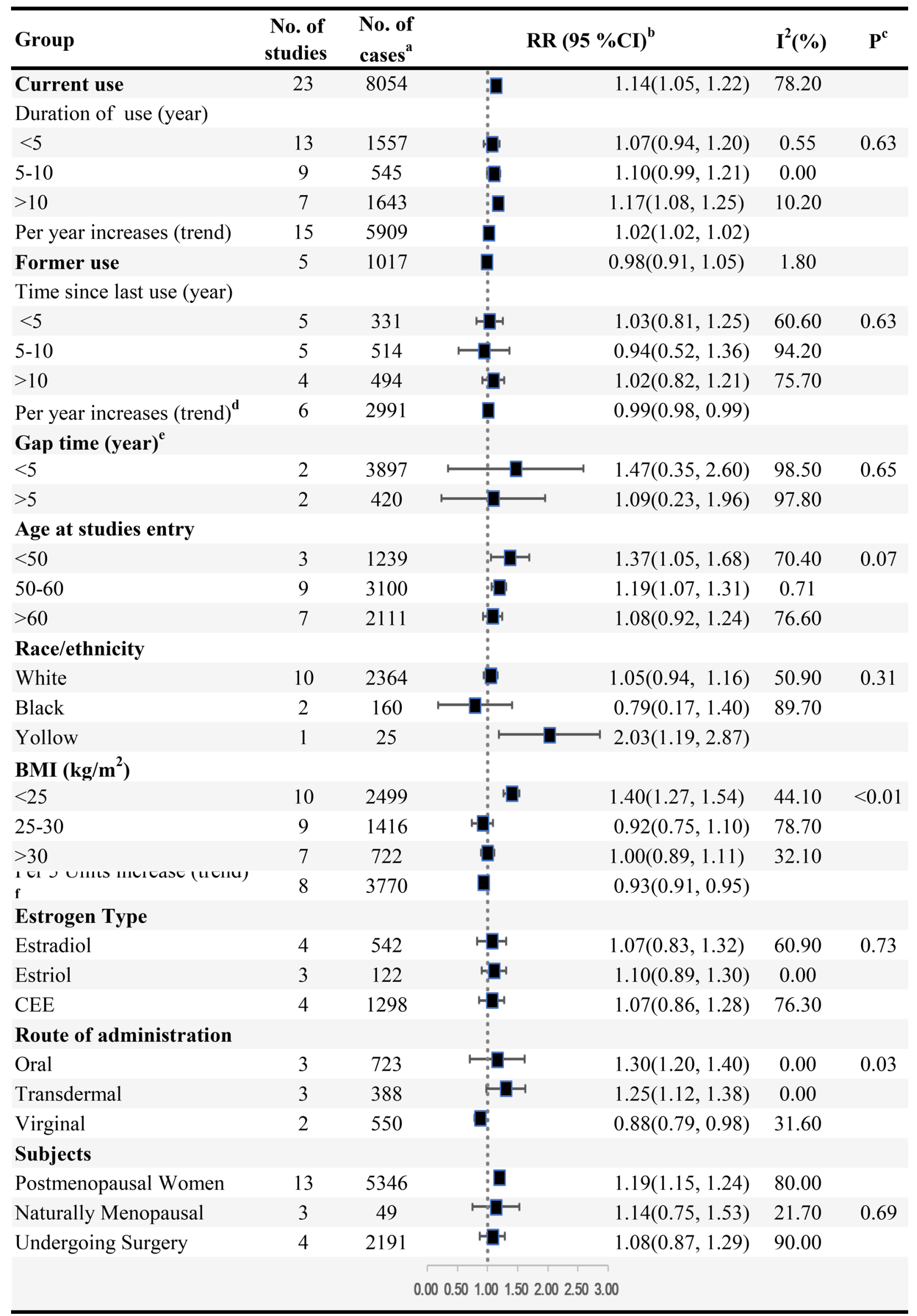


Continued

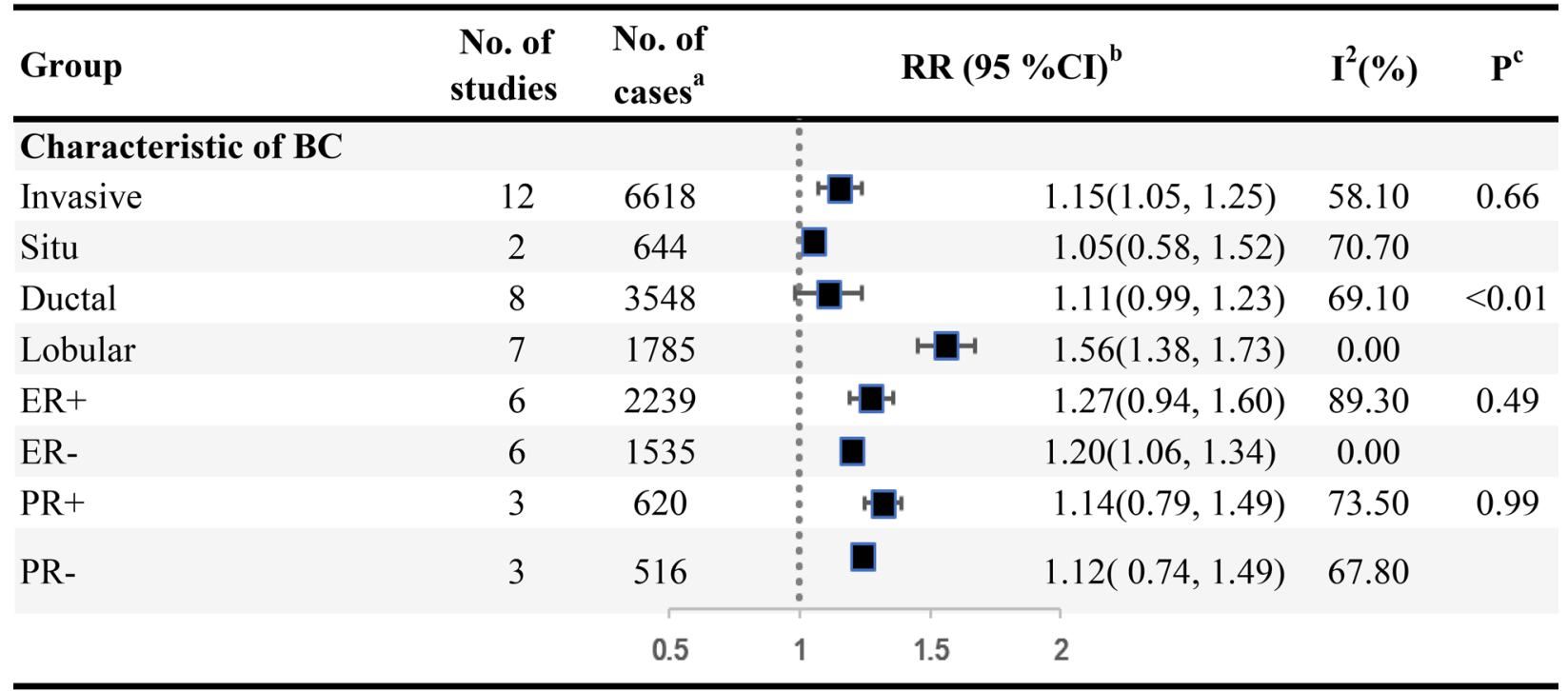

Note: Relative risk (RR) of BC was pooled in ET-users compared with non-users unless specially noted.

${ }^{\mathrm{a}}$ The number of cases was referred to $\mathrm{BC}$ patients developing from ET users which are exclusive of cases developing from non-users.

${ }^{\mathbf{b}}$ The square represents the RR for each category, and horizontal line across each square represents the $95 \%$ confidence interval. The dotted line in the middle represents an invalid line.

${ }^{\mathrm{c}} \mathrm{P}$ for interaction effect $<0.05$ was considered statistically significant.

${ }^{\mathrm{d}}$ Compared with current ET users.

${ }^{\mathrm{e}}$ Referred to time between menopause and starting use ET.

fCompared with lowest BMI (approximately at $18.5 \mathrm{~kg} / \mathrm{m} 2$ ) among ever ET users.

Abbreviations: ET, estrogen-only therapy; RR, relative risk; CI, confidence interval; CEE, conjugated equine estrogens; ER, estrogen-receptor; PR, progesterone receptor.

\section{Figure 4: ET and the risk of $B C$.}

and biases from inadequate adherence or limited sample size for long-time users, in addition of that, restricted numbers of studies with duration of use $>10$ years contributing to considerable biases. Moreover, some nonusers may start using HRT after long time, and we often observed smaller risk gap between "non-users" and longterm users than initial groups [84].

Interestingly, disparity of residual effects between ET and EPT on BC risk after stopping drugs was first revealed by this study. Although ET was found to be safer than EPT in regard to $\mathrm{BC}$ incident, the minor $\mathrm{BC}$ risk remained after drug withdrawal, which arose widespread concerns in previous studies $[6,9$, $26,40,67]$. Jones et al observed consistent results with us, compared with no previous HRT use, 2.1 percent and -1 percent increase in HR per year since last use among past users among participants receiving ET and EPT, respectively [6]. Moreover, differences tended to be obvious when stratified analyses were conducted according to duration of former HRT use, and participants with more than 5-year HRT use showed 2.4 and 0.88 magnitudes of ET and EPT related residual BC risk compared with non-users, respectively [9]. We failed to investigate the potential influences from duration of former HRT use due to limited evidence of the respect. The persistent residual $\mathrm{BC}$ risk made clinicians cautious when prescribing ET regimens, and more well-designed studies with long follow up was urgently needed to explore the effect of cessation of HRT use on BC risk.

Efforts to interpret inconsistent outcomes between RCT and observational studies suggested that BMI is an important modulator of HRT's influence on BC risk $[6,9$, $13,16,18,20,21,26,27,67]$. As interesting as all this is, among several large-scale observational studies, average BMI of participants was about $25 \mathrm{~kg} / \mathrm{m}^{2}$ (e.g. $24.8 \mathrm{~kg} / \mathrm{m}^{2}$ (the European Prospective Investigation into Cancer and Nutrition [16]); $26.2 \mathrm{~kg} / \mathrm{m}^{2}$ (the Million Women Study [27]); $25.7 \mathrm{~kg} / \mathrm{m}^{2}$ (the Breakthrough Generations Study (GBS) [6]); $24.9 \mathrm{~kg} / \mathrm{m}^{2}$ (the Nurses' Health Study [19])), which is notably lower than that in WHI trial $\left(28.5 \mathrm{~kg} / \mathrm{m}^{2}\right)$ that is the minimum risk point of our " $U$ " shaped of our curve. Thus, BMI disparity between observational studies and the RCT have possibility to lead underestimation of HRT-associated BC risk reported by WHI RCT. The 


\begin{tabular}{|c|c|c|c|c|c|c|}
\hline \multirow{2}{*}{$\begin{array}{l}\text { Group } \\
\text { Current }\end{array}$} & \multirow{2}{*}{$\begin{array}{c}\begin{array}{c}\text { No. of } \\
\text { studies }\end{array} \\
22\end{array}$} & \multirow{2}{*}{$\begin{array}{c}\begin{array}{c}\text { No. of } \\
\text { Cases }^{\text {a }}\end{array} \\
17584\end{array}$} & \multicolumn{2}{|c|}{$\operatorname{RR}(95 \% C I){ }^{b}$} & \multirow{2}{*}{$\frac{\mathbf{I}^{\mathbf{2}}(\boldsymbol{\%})}{92}$} & \multirow[t]{2}{*}{$\mathbf{P}^{\mathrm{c}}$} \\
\hline & & & - & $1.76(1.56,1.96)$ & & \\
\hline \multicolumn{7}{|l|}{ Duration of use(year) } \\
\hline$<5$ & 14 & 3517 & & $1.51(1.37,1.66)$ & 49.6 & $<0.01$ \\
\hline $5-10$ & 11 & 4396 & -1 & $1.95(1.66,2.23)$ & 72.6 & \\
\hline$>10$ & 6 & 669 & $\mapsto \square-1$ & $2.03(1.66,2.40)$ & 63.1 & \\
\hline Per year increases(trend) & 14 & 9064 & & $1.08(1.08,1.08)$ & & \\
\hline Former & 5 & 885 & & $1.06(0.93,1.20)$ & 48.3 & \\
\hline \multicolumn{7}{|l|}{ Time since last use(year) } \\
\hline$<5$ & 5 & 732 & & $1.09(1.00,1.18)$ & 0 & 0.39 \\
\hline $5-10$ & 5 & 503 & & $0.71(0.33,1.10)$ & 91.1 & \\
\hline$>10$ & 4 & 318 & & $1.04(0.92,1.17)$ & 0 & \\
\hline Per year increases $(\text { trend })^{c}$ & 6 & 4632 & & $0.95(0.94,0.96)$ & & \\
\hline \multicolumn{7}{|l|}{ Gap Time(year) } \\
\hline$<5$ & 3 & 4927 & & $1.83(1.45,2.21)$ & 88.4 & 0.15 \\
\hline$>5$ & 2 & 582 & & $1.27(0.75,1.80)$ & 90.6 & \\
\hline \multicolumn{7}{|l|}{ Age at studies entry } \\
\hline$<50$ & 3 & 1751 & & $1.93(1.06,2.80)$ & 94.5 & 0.09 \\
\hline $50-60$ & 11 & 12642 & & $1.90(1.62,2.17)$ & 94.3 & \\
\hline$>60$ & 4 & 2736 & & $1.62(1.04,2.21)$ & 91.3 & \\
\hline \multicolumn{7}{|l|}{ Race/ethnicity } \\
\hline White & 10 & 8809 & & $1.84(1.44,2.23)$ & 94.6 & $<0.01$ \\
\hline Black & 2 & 84 & & $1.30(0.96,1.63)$ & 0 & \\
\hline Yollow & 1 & 19 & $*$ & $8.74(5.52,13.86)$ & 1 & \\
\hline \multicolumn{7}{|l|}{ BMI (kg/m2) } \\
\hline$<25$ & 10 & 5113 & & $1.82(1.53,2.10)$ & 73.3 & 0.06 \\
\hline $25-30$ & 9 & 2140 & & & 52.9 & \\
\hline$>30$ & 7 & 823 & - & $1.44(1.20,1.67)$ & 61.1 & \\
\hline Per 5 units increase ${ }^{f}$ & 7 & 6572 & & $0.93(0.91,0.95)$ & & \\
\hline \multicolumn{7}{|l|}{ Progestin types } \\
\hline MPA & 10 & 5951 & & $1.45(1.14,1.76)$ & 88.1 & 0.74 \\
\hline NETA & 5 & 4445 & & $1.90(1.14,2.65)$ & 97.6 & \\
\hline Dydrogesterone & 2 & 765 & & $1.16(1.01,1.31)$ & 46.7 & \\
\hline \multicolumn{7}{|l|}{ Type of combination } \\
\hline Continuous & 10 & 3342 & $\longmapsto \square$ & $2.07(1.65,2.48)$ & 87.7 & 0.1 \\
\hline Sequential & 10 & 4250 & H- & $1.66(1.45,1.87)$ & 70.1 & \\
\hline \multicolumn{7}{|l|}{ Route of administration } \\
\hline Oral & 4 & 4431 & & $1.75(0.88,2.63)$ & 93.1 & 0.24 \\
\hline Transdermal & 4 & 427 & & $1.18(1.02,1.34)$ & 0 & \\
\hline
\end{tabular}




\begin{tabular}{|c|c|c|c|c|c|c|}
\hline Group & $\begin{array}{l}\text { No. of } \\
\text { studies }\end{array}$ & $\begin{array}{l}\text { No. of } \\
\text { Cases }^{a}\end{array}$ & \multicolumn{2}{|c|}{$\operatorname{RR}(95 \% C I)^{b}$} & $I^{2}(\%)$ & $\mathbf{P}^{\mathfrak{c}}$ \\
\hline \multicolumn{7}{|l|}{ Subjects } \\
\hline Postmenopausal Women & 9 & 6110 & $\mapsto \square-1$ & $1.78(1.49,2.07)$ & 91.9 & \\
\hline Naturally Menopausal & 3 & 167 & $\longmapsto \square$ & $2.61(2.05,3.17)$ & 0 & 0.1 \\
\hline Undergoing Surgery ${ }^{\mathrm{g}}$ & 1 & 1763 & $\square$ & $1.92(1.82,2.01)$ & & \\
\hline \multicolumn{7}{|l|}{ Characteristic of $\mathrm{BC}$} \\
\hline Invasive & 14 & 14538 & $\mapsto \square-1$ & $1.79(1.52,2.06)$ & 92.6 & 0.41 \\
\hline Situ & 4 & 778 & 1 & $1.38(1.01,1.76)$ & 84.2 & \\
\hline Ductal & 8 & 8073 & '- & $1.56(1.35,1.77)$ & 90.3 & 0.03 \\
\hline Lobular & 7 & 3082 & $\mapsto$ & $1.97(1.59,2.35)$ & 78.2 & \\
\hline ER+ & 5 & 3929 & $\longrightarrow$ & $2.24(1.39,3.09)$ & 97.3 & 0.04 \\
\hline ER- & 6 & 1828 & $\mathbf{H}$ & $1.36(1.16,1.56)$ & 39.8 & \\
\hline $\mathrm{PR}+$ & 2 & 863 & $\square$ & $1.41(1.14,1.67)$ & 0.71 & 0.99 \\
\hline PR- & 3 & 1049 & $r$ & $1.39(1.23,1.55)$ & 0.09 & \\
\hline \multicolumn{7}{|c|}{0.501 .001 .502 .002 .503 .003 .50} \\
\hline
\end{tabular}

Note: Relative risk (RR) of BC was pooled in EPT-users compared with non-users unless specially noted.

${ }^{\mathrm{a}}$ The number of cases was referred to BC patients developing from EPT users which are exclusive of cases developing from non-users.

${ }^{\mathbf{b}}$ The square represents the RR for each category, and horizontal line across each square represents the $95 \%$ confidence interval. The dotted line in the middle represents an invalid line.

${ }^{\mathrm{c}} \mathrm{P}$ for interaction effect $<0.05$ was considered statistically significant.

${ }^{\mathbf{d}}$ Compared with current EPT users.

${ }^{\mathrm{e}}$ Referred to time between menopause and starting use EPT.

${ }^{\mathrm{f}}$ Compared with lowest BMI (approximately at $18.5 \mathrm{~kg} / \mathrm{m} 2$ ) among ever EPT users.

${ }^{g}$ Woman who undergone hysterectomy or/and unilateral/bilateral salpingo-oophorectomy.

*This RR and its CI exceeding a majority of region of forest graph were not exhibited.

Abbreviations: RR, relative risk; CI, confidence interval; MPA, medroxyprogesterone acetate, NETA, norethisterone acetate; ER, estrogen-receptor; PR, progesterone receptor.

Figure 5: EPT and the risk of BC.

random-effect dose-response on account of generalized least squares trend estimation explored a reduction in $\mathrm{BC}$ incidence with the increase of BMI among HRT users, consistent results had been found in previous studies $[15,17,19,27]$. Furthermore, non-users with higher $\mathrm{BMI}$ are often associated with elevated risk of $\mathrm{BC}$, which was validated by a comprehensive dose-response metaanalysis [85], indicating that smallest BMI-associated 'risk gap' in $\mathrm{BC}$ between non-exposure and exposure existed in WHI, which is likely to lead no statistically significant magnitude of ET-related BC risk.

Combinations and administrations for HRT were critical modifiers, which were recognized in previous studies [5, 9, 22, 23, 25, 27, 63, 86]. Most studies suggested that $\mathrm{BC}$ risk was greater with continuous-combined than sequential regimen $[5,18,22,26,41,52]$, and the results were consistent with us. Oral progestin in sequential regimen can efficiently counteract the hyperplastic effect of estrogen [87], but no differences of BC risk between oral and transdermal EPT use were identified. Inversely, ET particularly orally administered estrogens are considered as counteract metabolic factors increasing the risk of BC, which were achieved by increasing insulin sensitivity and lowering circulating insulin levels [86], and this study suggested similar results that oral-ET had highest BC risk than transdermal and virginal use. 
The notable strength of the dose-response metaanalysis with systematic review was to clarify the associations between HRT use and the risk of BC and related modifiers, and to the best of our knowledge, we are the first to explore dose-response relationships of changing yearto-year for HRT use or withdrawal and BMI among HRT users with BC risk. Nevertheless, some limitations of our study should be acknowledged. Firstly, considering that our meta-analysis was based on study-level, our results therefore exhibited a lack of reliability relative to previous individual patient data meta-analysis [15]. Most data were extracted from outcomes of primary analyses, but others such as age and race/ethnicity were roughly extracted from characteristics of sample population, which therefore contributed to failure of draw conclusions on subgroup analyses of them. Secondly, we failed to investigate the influences of mammary screening and breast density on BC risk in subjects using HRT duo to limited related studies. Lastly, stratified analyses were conducted in our study, and most eligible studies adjusted related variables, identifying several key factors such as duration of HRT use or quit, BMI and gap time. However, high heterogeneity in this study was documented coming from clinical and methodological aspects, and unmeasured or residual modifiers can't be eliminated.

\section{CONCLUSIONS}

This study supports that current use of ET, EPT and ever use of tibolone increased the risk of BC, whereas no association of former ET, EPT use or ever PT use with $\mathrm{BC}$ risk is identified. For obvious heterogeneity among included studies is presented, these outcomes should be interpreted with caution. We also further summary current epidemiological evidences according to sever proposed interactions, suggesting that duration of HRT use, time since last HRT use, gap time and BMI are potential modifiers. HRT users regardless of ET or EPT with longer duration of use are associated with higher BC risk with 8-10 years' onset peaks, but longer time from last HRT use, longer gap time and higher BMI contribute to attenuated $\mathrm{BC}$ risk. Both regimens are associated with higher risk of lobular $\mathrm{BC}$ than ductal $\mathrm{BC}$, and more ERpositive $\mathrm{BC}$ cases than ER-negative $\mathrm{BC}$ were detected among EPT users. More studies with larger sample size and better control of these effect-modifiers will be needed to reveal dose-response effects on HRT regimens or their modifiers and the risk of $\mathrm{BC}$.

\section{Abbreviations}

HRT, hormone replacement therapy, ET, estrogenalone therapy; EPT, estrogen plus progestin therapy; $\mathrm{BC}$, breast cancer; WHI, women health initial; RCT randomized clinical trial; $\mathrm{RR}$, relative risk; $\mathrm{CI}$, confidence interval; NOS, Newcastle-Ottawa quality assessment scale; ER, estrogen receptor; $\mathrm{PR}$, progesterone receptor;
PT, progestin-only therapy; MPA, medroxyprogesterone acetate; NETA, norethisterone acetate; BMI, body mass index; CEE, conjugated equine estrogens.

\section{Author contributions}

H.Y.L. and K.W. conceived the study idea. F.L. and L.C. performed literature search, study selection, data extraction and quality assessment. Y.M.L. performed statistical analyses. X.Z. interpreted results of statistical analyses. K.W. drafted the initial manuscript. H.Y.L. made critical comment and revision for the initial manuscript. H.Y.L. had primary responsibility for the final content. All authors reviewed and approved the final manuscript.

\section{ACKNOWLEDGMENTS}

We thank Dr Guo-Chao Zhong (Department of Hepatobiliary Surgery, The Second Affiliated Hospital of Chongqing Medical University, Chongqing 400016, China) for his assistance in our language modification.

\section{CONFLICTS OF INTEREST}

The authors declare that there are no conflicts of interest.

\section{FUNDING}

This study was supported by grants from National Key Clinical Specialty Construction Program of China, Chinese Academy of Medical Sciences \& Peking Union Medical College (2014BAI08B03), Zhejiang Province Key Project of Science and Technology (2014BAI08B00). The funder of this study had no role in the decisions about the design and conduct of the study; collection, management, analysis, or interpretation of the data; or the preparation, review, or approval of the manuscript. The views expressed in this review are the opinions of the authors.

\section{REFERENCES}

1. Rossouw JE, Anderson GL, Prentice RL, LaCroix AZ, Kooperberg C, Stefanick ML, Jackson RD, Beresford SA, Howard BV, Johnson KC, Kotchen JM, Ockene J. Risks and benefits of estrogen plus progestin in healthy postmenopausal women: principal results From the Women's Health Initiative randomized controlled trial. JAMA. 2002; 288:321-33.

2. Grosse Y, Baan R, Straif K, Secretan B, El Ghissassi F, Bouvard V, Benbrahim-Tallaa L, Guha N, Galichet L, Cogliano V. A review of human carcinogens--Part A: pharmaceuticals. Lancet Oncol. 2009; 10:13-4.

3. Pharmaceuticals. Volume 100 A. A review of human carcinogens. IARC Monogr Eval Carcinog Risks Hum. 2012; 100:1-401. 
4. Siegel RL, Miller KD, Jemal A. Cancer statistics, 2016. CA Cancer J Clin. 2016; 66:7-30. https://doi.org/10.3322/ caac. 21332 .

5. Roman M, Sakshaug S, Graff-Iversen S, Vangen S, Weiderpass E, Ursin G, Hofvind S. Postmenopausal hormone therapy and the risk of breast cancer in Norway. Int J Cancer. 2016; 138:584-93. https://doi.org/10.1002/ ijc. 29810 .

6. Jones ME, Schoemaker MJ, Wright L, McFadden E, Griffin J, Thomas D, Hemming J, Wright K, Ashworth A, Swerdlow AJ. Menopausal hormone therapy and breast cancer: what is the true size of the increased risk? Br J Cancer. 2016. https://doi.org/10.1038/bjc.2016.231.

7. Chlebowski RT, Rohan TE, Manson JE, Aragaki AK, Kaunitz A, Stefanick ML, Simon MS, Johnson KC, Wactawski-Wende J, O’Sullivan MJ, Adams-Campbell LL, Nassir R, Lessin LS, et al. Breast Cancer After Use of Estrogen Plus Progestin and Estrogen Alone: Analyses of Data From 2 Women's Health Initiative Randomized Clinical Trials. JAMA Oncol. 2015; 1:296-305. https://doi. org/10.1001/jamaoncol.2015.0494.

8. Thorbjarnardottir T, Olafsdottir EJ, Valdimarsdottir UA, Olafsson O, Tryggvadottir L. Oral contraceptives, hormone replacement therapy and breast cancer risk: A cohort study of 16928 women 48 years and older. Acta Oncologica. 2014; 53:752-8.

9. Fournier A, Mesrine S, Dossus L, Boutron-Ruault MC, Clavel-Chapelon F, Chabbert-Buffet N. Risk of breast cancer after stopping menopausal hormone therapy in the E3N cohort. Breast Cancer Research and Treatment. 2014; 145:535-43.

10. Pizot C, Boniol M, Mullie P, Koechlin A, Boniol M, Boyle P, Autier P. Physical activity, hormone replacement therapy and breast cancer risk: A meta-analysis of prospective studies. European Journal of Cancer. 2016; 52:138-54.

11. Reeves GK, Beral V, Green J, Gathani T, Bull D, Million Women Study C. Hormonal therapy for menopause and breast-cancer risk by histological type: a cohort study and meta-analysis. Lancet Oncology. 2006; 7:910-8. https://doi. org/10.1016/s1470-2045(06)70911-1.

12. Greiser CM, Greiser EM, Doren M. Menopausal hormone therapy and risk of breast cancer: a meta-analysis of epidemiological studies and randomized controlled trials. Hum Reprod Update. 2005; 11:561-73. https://doi. org/10.1093/humupd/dmi031.

13. Chlebowski RT, Anderson GL, Aragaki AK, Prentice R. Breast Cancer and Menopausal Hormone Therapy by Race/ Ethnicity and Body Mass Index. Journal of the National Cancer Institute. 2016; 108.

14. Nanda K, Bastian LA, Schulz K. Hormone replacement therapy and the risk of death from breast cancer: a systematic review. Am J Obstet Gynecol. 2002; 186:325-34.

15. Beral V. Breast cancer and hormone replacement therapy: Collaborative reanalysis of data from 51 epidemiological studies of 52,705 women with breast cancer and 108,411 women without breast cancer. Lancet. 1997; 350:1047-59.

16. Ritte R, Lukanova A, Berrino F, Dossus L, Tjonneland A, Olsen A, Overvad TF, Overvad K, Clavel-Chapelon F, Fournier A, Fagherazzi G, Rohrmann S, Teucher B, et al. Adiposity, hormone replacement therapy use and breast cancer risk by age and hormone receptor status: a large prospective cohort study. Breast Cancer Res. 2012; 14:R76. https://doi.org/10.1186/bcr3186.

17. Feigelson HS, Jonas CR, Teras LR, Thun MJ, Calle EE. Weight Gain, Body Mass Index, Hormone Replacement Therapy, and Postmenopausal Breast Cancer in a Large Prospective Study. Cancer Epidemiology Biomarkers and Prevention. 2004; 13:220-4.

18. Saxena T, Lee E, Henderson KD, Clarke CA, West D, Marshall SF, Deapen D, Bernstein L, Ursin G. Menopausal hormone therapy and subsequent risk of specific invasive breast cancer subtypes in the California Teachers Study. Cancer Epidemiology Biomarkers and Prevention. 2010; 19:2366-78.

19. Kotsopoulos J, Chen WY, Gates MA, Tworoger SS, Hankinson SE, Rosner BA. Risk factors for ductal and lobular breast cancer: results from the nurses' health study. Breast Cancer Res. 2010; 12:R106. https://doi.org/10.1186/bcr2790.

20. Calle EE, Feigelson HS, Hildebrand JS, Teras LR, Thun MJ, Rodriguez C. Postmenopausal hormone use and breast cancer associations differ by hormone regimen and histologic subtype. Cancer. 2009; 115:936-45. https://doi. org/10.1002/cncr.24101.

21. Rosenberg L, Palmer JR, Wise LA, Adams-Campbell LL. A prospective study of female hormone use and breast cancer among black women. Arch Intern Med. 2006; 166:760-5. https://doi.org/10.1001/archinte.166.7.760.

22. Lyytinen H, Pukkala E, Ylikorkala O. Breast cancer risk in postmenopausal women using estradiol-progestogen therapy. Obstet Gynecol. 2009; 113:65-73. https://doi. org/10.1097/AOG.0b013e31818e8cd6.

23. Ewertz M, Mellemkjaer L, Poulsen AH, Friis S, Sorensen HT, Pedersen L, McLaughlin JK, Olsen JH. Hormone use for menopausal symptoms and risk of breast cancer. A Danish cohort study. Br J Cancer. 2005; 92:1293-7. https:// doi.org/10.1038/sj.bjc.6602472.

24. Stahlberg C, Pedersen AT, Lynge E, Andersen ZJ, Keiding N, Hundrup YA, Obel EB, Ottesen B. Increased risk of breast cancer following different regimens of hormone replacement therapy frequently used in Europe. International Journal of Cancer. 2004; 109:721-7.

25. Espié M, Daures JP, Chevallier T, Mares P, Micheletti MC, De Reilhac P. Breast cancer incidence and hormone replacement therapy: Results from the MISSION study, prospective phase. Gynecological Endocrinology. 2007; 23:391-7.

26. Brinton LA, Richesson D, Leitzmann MF, Gierach GL, Schatzkin A, Mouw T, Hollenbeck AR, Lacey JV Jr. Menopausal hormone therapy and breast cancer risk in the NIH-AARP Diet and Health Study Cohort. Cancer 
Epidemiol Biomarkers Prev. 2008; 17:3150-60. https://doi. org/10.1158/1055-9965.epi-08-0435.

27. Beral V, Reeves G, Bull D, Green J, Million Women Study C. Breast Cancer Risk in Relation to the Interval Between Menopause and Starting Hormone Therapy. Journal Of the National Cancer Institute. 2011; 103:296-305. https://doi. org/10.1093/jnci/djq527.

28. Grady D, Gebretsadik T, Kerlikowske K, Ernster V, Petitti D. Hormone replacement therapy and endometrial cancer risk: a meta-analysis. Obstet Gynecol. 1995; 85:304-13. https:// doi.org/10.1016/0029-7844(94)00383-o.

29. Key TJ, Verkasalo PK. Endogenous hormones and the aetiology of breast cancer. Breast Cancer Res. 1999; 1:18-21.

30. Fisher B, Costantino JP, Wickerham DL, Cecchini RS, Cronin WM, Robidoux A, Bevers TB, Kavanah MT, Atkins JN, Margolese RG, Runowicz CD, James JM, Ford LG, et al. Tamoxifen for the prevention of breast cancer: current status of the National Surgical Adjuvant Breast and Bowel Project P-1 study. J Natl Cancer Inst. 2005; 97:1652-62. https://doi.org/10.1093/jnci/dji372.

31. Clarke MJ. Ovarian ablation in breast cancer, 1896 to 1998 : milestones along hierarchy of evidence from case report to Cochrane review. BMJ. 1998; 317:1246-8.

32. Anderson GL, Limacher $\mathrm{M}$, Assaf AR, Bassford $\mathrm{T}$, Beresford SA, Black H, Bonds D, Brunner R, Brzyski R, Caan B, Chlebowski R, Curb D, Gass M, et al. Effects of conjugated equine estrogen in postmenopausal women with hysterectomy: the Women's Health Initiative randomized controlled trial. JAMA. 2004; 291:1701-12. https://doi. org/10.1001/jama.291.14.1701.

33. Chen WY, Manson JE, Hankinson SE, Rosner B, Holmes MD, Willett WC, Colditz GA. Unopposed estrogen therapy and the risk of invasive breast cancer Nurses' Health Study. Archives of Internal Medicine. 2006; 166:1027-32.

34. Beral V. Breast cancer and hormone-replacement therapy in the Million Women Study. Lancet. 2003; 362:419-27.

35. Suba Z. Circulatory estrogen level protects against breast cancer in obese women. Recent Patents on Anti-Cancer Drug Discovery. 2013; 8:154-67.

36. Coelingh Bennink HJ, Verhoeven C, Dutman AE, Thijssen J. The use of high-dose estrogens for the treatment of breast cancer. Maturitas. 2017; 95:11-23. https://doi.org/10.1016/j. maturitas.2016.10.010.

37. Moher D, Liberati A, Tetzlaff J, Altman DG. Preferred reporting items for systematic reviews and meta-analyses: the PRISMA Statement. Open Med. 2009; 3:e123-30.

38. Wells G, Shea B, O'Connell D, Robertson J, Peterson J, Welch V, Losos M, Tugwell P. The Newcastle-Ottawa Scale (NOS) for assessing the quality of non-randomised studies in meta-analyses. 2000.

39. DerSimonian R, Laird N. Meta-analysis in clinical trials. Control Clin Trials. 1986; 7:177-88.

40. Lai JN, Wu CT, Chen PC, Huang CS, Chow SN, Wang JD. Increased risk for invasive breast cancer associated with hormonal therapy: a nation-wide random sample of 65,723 women followed from 1997 to 2008. PLoS One. 2011; 6: e25183. https://doi.org/10.1371/journal.pone.0025183.

41. Olsson HL, Ingvar C, Bladstrom A. Hormone replacement therapy containing progestins and given continuously increases breast carcinoma risk in Sweden. Cancer. 2003; 97:1387-92. https://doi.org/10.1002/cncr.11205.

42. Jernstrom H, Bendahl PO, Lidfeldt J, Nerbrand C, Agardh CD, Samsioe G. A prospective study of different types of hormone replacement therapy use and the risk of subsequent breast cancer: the women's health in the Lund area (WHILA) study (Sweden). Cancer Causes Control. 2003; 14:673-80.

43. Chen CL, Weiss NS, Newcomb P, Barlow W, White E. Hormone replacement therapy in relation to breast cancer. Journal of the American Medical Association. 2002; 287:734-41.

44. Tjonneland A, Christensen J, Thomsen BL, Olsen A, Overvad K, Ewertz M, Mellemkjaer L. Hormone replacement therapy in relation to breast carcinoma incidence rate ratios: a prospective Danish cohort study. Cancer. 2004; 100:2328-37. https://doi.org/10.1002/ cncr. 20250.

45. Reeves GK, Beral V, Green J, Gathani T, Bull D. Hormonal therapy for menopause and breast-cancer risk by histological type: a cohort study and meta-analysis. Lancet Oncol. 2006; 7:910-8. https://doi.org/10.1016/s14702045(06)70911-1.

46. Manjer J, Malina J, Berglund G, Bondeson L, Garne JP, Janzon L. Increased incidence of small and welldifferentiated breast tumours in post-menopausal women following hormone-replacement therapy. International Journal of Cancer. 2001; 92:919-22.

47. Orsini N, Bellocco R, Greenland S. Generalized least squares for trend estimation of summarized dose-response data. Stata J. 2006:40-57.

48. Greenland S, Longnecker MP. Methods for trend estimation from summarized dose-response data, with applications to meta-analysis. Am J Epidemiol. 1992; 135:1301-9.

49. Desquilbet L, Mariotti F. Dose-response analyses using restricted cubic spline functions in public health research. Stat Med. 2010; 29:1037-57. https://doi.org/10.1002/ $\operatorname{sim} .3841$.

50. Orsini N, Li R, Wolk A, Khudyakov P, Spiegelman D. Metaanalysis for linear and nonlinear dose-response relations: examples, an evaluation of approximations, and software. Am J Epidemiol. 2012; 175:66-73. https://doi.org/10.1093/ aje/kwr265.

51. Hamling J, Lee P, Weitkunat R, Ambuhl M. Facilitating meta-analyses by deriving relative effect and precision estimates for alternative comparisons from a set of estimates presented by exposure level or disease category. Stat Med. 2008; 27:954-70. https://doi.org/10.1002/sim.3013.

52. Bakken K, Alsaker E, Eggen AE, Lund E. Hormone replacement therapy and incidence of hormone-dependent 
cancers in the Norwegian women and cancer study. International Journal of Cancer. 2004; 112:130-4.

53. Higgins JP, Thompson SG. Controlling the risk of spurious findings from meta-regression. Stat Med. 2004; 23: 1663-82. https://doi.org/10.1002/sim.1752.

54. Higgins JP, Thompson SG. Quantifying heterogeneity in a meta-analysis. Stat Med. 2002; 21:1539-58. https://doi. org/10.1002/sim.1186.

55. Begg CB, Mazumdar M. Operating characteristics of a rank correlation test for publication bias. Biometrics. 1994; 50:1088-101.

56. Egger M, Davey Smith G, Schneider M, Minder C. Bias in meta-analysis detected by a simple, graphical test. BMJ. 1997; 315:629-34.

57. LaCroix AZ, Chlebowski RT, Manson JE, Aragaki AK, Johnson KC, Martin L, Margolis KL, Stefanick ML, Brzyski R, Curb JD, Howard BV, Lewis CE, WactawskiWende J. Health outcomes after stopping conjugated equine estrogens among postmenopausal women with prior hysterectomy: a randomized controlled trial. JAMA. 2011; 305:1305-14. https://doi.org/10.1001/jama.2011.382.

58. Prentice RL, Chlebowski RT, Stefanick ML, Manson JE, Pettinger M, Hendrix SL, Hubbell FA, Kooperberg C, Kuller LH, Lane DS, McTiernan A, Jo O'Sullivan M, Rossouw JE, et al. Estrogen plus progestin therapy and breast cancer in recently postmenopausal women. American Journal of Epidemiology. 2008; 167:1207-16.

59. Luo J, Cochrane BB, Wactawski-Wende J, Hunt JR, Ockene JK, Margolis KL. Effects of menopausal hormone therapy on ductal carcinoma in situ of the breast. Breast Cancer Research and Treatment. 2013; 137:915-25.

60. Fournier A, Berrino F, Riboli E, Avenel V, Clavel-Chapelon F. Breast cancer risk in relation to different types of hormone replacement therapy in the E3N-EPIC cohort. International Journal of Cancer. 2005; 114:448-54.

61. Fournier A, Fabre A, Mesrine S, Boutron-Ruault MC, Berrino F, Clavel-Chapelon F. Use of different postmenopausal hormone therapies and risk of histologyand hormone receptor-defined invasive breast cancer. Journal Of Clinical Oncology. 2008; 26:1260-8. https://doi. org/10.1200/jco.2007.13.4338.

62. Fournier A, Mesrine S, Boutron-Ruault MC, ClavelChapelon F. Estrogen-progestagen menopausal hormone therapy and breast cancer: does delay from menopause onset to treatment initiation influence risks? J Clin Oncol. 2009; 27:5138-43. https://doi.org/10.1200/jco.2008.21.6432.

63. Suhrke P, Zahl PH. Breast cancer incidence and menopausal hormone therapy in Norway from 2004 to 2009: A registerbased cohort study. Cancer Medicine. 2015; 4:1303-8.

64. Persson I, Weiderpass E, Bergkvist L, Bergstrom R, Schairer C. Risks of breast and endometrial cancer after estrogen and estrogen-progestin replacement. Cancer Causes Control. 1999; 10:253-60.

65. Sourander L, Rajala T, Raiha I, Makinen J, Erkkola R, Helenius H. Cardiovascular and cancer morbidity and mortality and sudden cardiac death in postmenopausal women on oestrogen replacement therapy (ERT). Lancet. 1998; 352:1965-9. https:// doi.org/10.1016/s0140-6736(98)05066-1.

66. Adami HO, Persson I, Hoover R, Schairer C, Bergkvist L. Risk of cancer in women receiving hormone replacement therapy. International Journal of Cancer. 1989; 44:833-9.

67. Schairer C, Lubin J, Troisi R, Sturgeon S, Brinton L, Hoover R. Menopausal estrogen and estrogen-progestin replacement therapy and breast cancer risk. Journal of the American Medical Association. 2000; 283:485-91.

68. Lando JF, Heck KE, Brett KM. Hormone replacement therapy and breast cancer risk in a nationally representative cohort. American Journal of Preventive Medicine. 1999; 17:176-80.

69. Gapstur SM, Morrow M, Sellers TA. Hormone replacement therapy and risk of breast cancer with a favorable histology: Results of the Iowa Women's Health Study. Journal of the American Medical Association. 1999; 281:2091-7.141.

70. Mills PK, Beeson WL, Phillips RL, Fraser GE. Prospective study of exogenous hormone use and breast cancer in Seventh-day Adventists. Cancer. 1989; 64:591-7.

71. de Lignieres B, de Vathaire F, Fournier S, Urbinelli R, Allaert F, Le MG, Kuttenn F. Combined hormone replacement therapy and risk of breast cancer in a French cohort study of 3175 women. Climacteric. 2002; 5:332-40.

72. Risch HA, Howe GR. Menopausal hormone usage and breast cancer in Saskatchewan: a record-linkage cohort study. Am J Epidemiol. 1994; 139:670-83.

73. Schuurman AG, Van den Brandt PA, Goldbohm RA. Exogenous hormone use and the risk of postmenopausal breast cancer: Results from the Netherlands Cohort Study. Cancer Causes and Control. 1995; 6:416-24.

74. Lobo RA. Hormone-replacement therapy: current thinking. Nat Rev Endocrinol. 2016; advance online publication. https://doi.org/10.1038/nrendo.2016.164.

75. Althuis MD, Fergenbaum JH, Garcia-Closas M, Brinton LA, Madigan MP, Sherman ME. Etiology of hormone receptordefined breast cancer: a systematic review of the literature. Cancer Epidemiol Biomarkers Prev. 2004; 13:1558-68.

76. IARC Working Group on the Evaluation of Carcinogenic Risks to Humans. Diesel and gasoline engine exhausts and some nitroarenes. Iarc monogr eval carcinog risks hum. 2014; 105:9-699.

77. Stahlberg C, Pederson AT, Lynge E, Ottesen B. Hormone replacement therapy and risk of breast cancer: the role of progestins. Acta Obstet Gynecol Scand. 2003; 82:335-44.

78. Santen RJ, Pinkerton J, McCartney C, Petroni GR. Risk of breast cancer with progestins in combination with estrogen as hormone replacement therapy. J Clin Endocrinol Metab. 2001; 86:16-23. https://doi.org/10.1210/jcem.86.1.7269.

79. Russo J, Lareef MH, Tahin Q, Hu YF, Slater C, Ao X, Russo IH. 17Beta-estradiol is carcinogenic in human breast epithelial cells. J Steroid Biochem Mol Biol. 2002; 80:149-62.

80. Russo J, Russo IH. Genotoxicity of steroidal estrogens. Trends Endocrinol Metab. 2004; 15:211-4. https://doi. org/10.1016/j.tem.2004.05.007. 
81. Groshong SD, Owen GI, Grimison B, Schauer IE, Todd MC, Langan TA, Sclafani RA, Lange CA, Horwitz KB. Biphasic regulation of breast cancer cell growth by progesterone: role of the cyclin-dependent kinase inhibitors, p21 and p27(Kip1). Mol Endocrinol. 1997; 11:1593-607. https:// doi.org/10.1210/mend.11.11.0006.

82. Jordan VC, Ford LG. Paradoxical clinical effect of estrogen on breast cancer risk: a "new" biology of estrogen-induced apoptosis. Cancer Prev Res (Phila). 2011; 4:633-7. https:// doi.org/10.1158/1940-6207.capr-11-0185.

83. Santen RJ, Yue W, Heitjan DF. Modeling of the growth kinetics of occult breast tumors: Role in interpretation of studies of prevention and menopausal hormone therapy. Cancer Epidemiology Biomarkers and Prevention. 2012; 21:1038-48.

84. Lee SA, Ross RK, Pike MC. An overview of menopausal oestrogen-progestin hormone therapy and breast cancer risk. Br J Cancer. 2005; 92:2049-58. https://doi.org/10.1038/ sj.bjc. 6602617 .
85. Chan DS, Vieira AR, Aune D, Bandera EV, Greenwood DC, McTiernan A, Navarro Rosenblatt D, Thune I, Vieira R, Norat T. Body mass index and survival in women with breast cancer-systematic literature review and meta-analysis of 82 follow-up studies. Ann Oncol. 2014; 25:1901-14. https://doi.org/10.1093/annonc/mdu042.

86. Campagnoli C, Clavel-Chapelon F, Kaaks R, Peris C, Berrino F. Progestins and progesterone in hormone replacement therapy and the risk of breast cancer. J Steroid Biochem Mol Biol. 2005; 96:95-108. https://doi. org/10.1016/j.jsbmb.2005.02.014.

87. Effects of hormone replacement therapy on endometrial histology in postmenopausal women. The Postmenopausal Estrogen/Progestin Interventions (PEPI) Trial. The Writing Group for the PEPI Trial. Jama. 1996; 275:370-5. 